\title{
The Circuit Councils: Rusty Hinges of Federal Judicial Administration
}

Peter Graham Fish $\uparrow$

The Administrative Office Act of $1939^{1}$ fundamentally changed the judicial system of the country. ${ }^{2}$ Ever since 1789 that system had rested on the district judge as the responsible administrator in his district. ${ }^{3}$ Now, observed Senior Circuit Judge John J. Parker, the 1939 Act "placed in the council of the circuit responsibility for supervision of the administration." 4

After 1939 the federal judiciary possessed a complete administrative system. The Judicial Conference of the United States, founded in 1922 and composed of the ranking judge from each court of appeals later joined by a district judge representative from each circuit and representatives from the special courts, was charged with making a wide range of policies related to the administration of the federal courts. ${ }^{5}$ The 1939 Act provided for a housekeeping agency, the Administrative Office of the United States Courts, and a circuit council in each of the circuits. The latter institutions constituted the "grass-roots" element in the system. On them sat all members of each circuit's court of appeals. Their tasks were to implement Conference policies as well as various statutory duties imposed by Congress.

To numerous observers, these regional institutions have never developed into the administrative cornerstones originally intended. Little more than a decade after their establishment, Professor Maynard Pirsig

† Assistant Professor of Political Science, Duke University.

This article is part of a larger study on federal judicial administration to be published by the Princeton University Press.

153 Stat. 1223, 28 U.S.C. $\$ \S 601,603,606,608$ (1964).

2 Hearings on S. 1050, S. 1051, S. 1052, S. 1053, S. 1054, H.R. 138 Before a Subcomm. of the Senate Comm. on the Judiciary, 77th Cong., 1st Sess. 27 (1941) (statement of John J. Parker) [hereinafter cited as Hearings on S. 1050].

3 Id.

4 Id.

5 Establishment of the Judicial Conference (42 Stat. 837 (1922)); Court of Claims representation (70 Stat. 497 (1956)); district court representation (71 Stat. 476 (1957)); Court of Customs and Patent Appeals representation (75 Stat. 521 (1961)). 
assailed the councils. ${ }^{6} \mathrm{His}$ criticism went unheeded, ${ }^{7}$ but that contained in a lengthy report to the Senate Appropriations Committee, commonly known as the Cotter Report, after the committee's chief counsel, fell with heavier impact. ${ }^{8}$

Cotter's 1959 Report charged that there existed "a grave lack of administrative direction in the operation of the business of the United States courts," and that this defect resulted in "serious and, in some cases, shocking conditions of delay and neglect of cases on court dockets." And it laid a major share of the blame for both cause and effect on the circuit councils. ${ }^{10}$

Subsequent congressional criticism spurred the Judicial Conference to undertake a study of the powers and responsibilities of the councils. ${ }^{11}$ A committee of the Conference reported in March 1961 that the "present statute 12 is adequate," and recommended no fundamental changes in the organization or powers of the councils. ${ }^{13}$ Nevertheless, criticism has continued to emanate from congressmen and judges alike. ${ }^{14}$

The on-going controversy over the nature and functions of the circuit councils has raised important issues meriting examination. Foremost among them are those relating to council organization, roles, and powers, as contemplated by the framers of the Administrative Office Act, and as altered by subsequent statutes and practice or absence thereof. To what extent have the councils acted as an integrative force in the federal judiciary's highly decentralized administrative system? Conversely, to what extent have they interjected a disintegrative element

6 See Pirsig, A Survey of Judicial Councils, Judicial Conferences and Administrative Directors, 47 BRIEF 181-205 (1952).

7 Administrative Office of the United States Courts, Survey of the Legal Profession Containing Critical Comments on the Judicial Councils and Judicial Conferences of the Circuits in the Federal System, Memorandum No. 3, March 15, 1955.

8 Staff of Senate Comm. on Appropriations, 86th CoNg., 2d Sess., Field Study of the Operations of United States Courts (Comm. Print. 1959).

9 Id. at 1 .

10 See id. at $84-84 \mathrm{~b}$.

11 1959 Annual Report of the Proceedings of the Judicial Conference of the UnIted States [AND] Annual Report of the DiREctor of the Administrative Office OF THE UNITED STATES COURTS 290 [hereinafter such annual reports will be cited as Judicial CONFERENGe REPORT]; 1960 JUdicial CONFERENGE REPORT 47.

1228 U.S.C. $\$ 332$ (1964).

13 H.R. REP. No. 201, 87th Cong., 1st Sess. $9^{\prime}$ (1961) [hereinafter cited as H.R. REP. No. 201].

14 See Tydings, The Congress and the Courts: Helping the Judiciary to Help Itself, 52 A.B.A.J. 321, 324 (1966); Address of the Honorable Earl Warren, 35 F.R.D. 181, 185 (1964); Hearings on S. 3055, S. 3060, S. 3061, S. 3062 Before the Subcomm. on Improvements in Judicial Machinery of the Senate Comm. on the Judiciary, 90th Cong., 2d Sess. 248 (1968) (statement of Joseph D. Tydings) [hereinafter cited as Hearings on S. 3055]. 
into that system? Respecting the interaction between councils and district judges, what strategies are available to those councils which seek to perform their statutory duties? Why do some councils act affirmatively while others act not at all? And when the circuit judges fail to act in matters of maladministration, what recourse exists for aggrieved parties, either within the present administrative system or under a system reformed in assorted ways?

\section{The Framers and Their Intentions}

The much-maligned circuit councils are primarily the handiwork of Chief Justice Charles Evans Hughes, and their design reflects his conception of the ideal administrative model. Such a model was one which incorporated the essence of federalism, which emphasized personalism and localism; for Hughes deeply believed that "[w]e are apt to look too far away for the accomplishment of reforms."15

Thus he urged on the 1938 session of the Judicial Conference

a mechanism through which there could be a concentration of responsibility in the various Circuits-immediate responsibility for the work of the courts in the Circuits, with power and authority to make the supervision all that is necessary to insure competence in the work of all of the judges of the various districts within the Circuit. ${ }^{16}$

Such a mechanism was only logical, Hughes asserted, because the circuit judges personally knew the trial judges and knew their capacities from examining the lower court records. ${ }^{17}$ Consequently, when complaints arose, the appellate judges had at their disposal means of ascertaining the validity of such allegations. ${ }^{18}$

The Chief Justice believed that direct and on-the-spot supervision would prove infinitely more effective than centralizing supervisory powers in the chief's office as had been proposed earlier by Attorney General Homer Cummings. ${ }^{19}$ Hughes thought the plan advanced by Cummings would impose on the chief justice "a great deal of labor and circumlocution." 20 Moreover, it opened him and his Court to

15 Chief Justice Hughes Addresses Judicial Conference of the Fourth Circuit, 18 A.B.A.J. 445,447 (1932).

16 Supreme Court of the United States, Administration in the Federal CourtsAdministrative Office Bill 14-15 (extract from proceedings of the Judicial Conference, Sept. 30, 1938 at 172-92) [hereinafter cited as Administration in the Federal Courts].

17 Id. at 17-18.

18 Id.

191937 ATr'y. GEN. ANN. REP. 5; S. 3212, 75th Cong., 3d Sess. (1938).

20 Administration in the Federal Courts 18. 
attacks from those disadvantaged by administrative failings in remote federal trial courts. It had been the acknowledged existence of such defects which had given a ring of truth to President Franklin D. Roosevelt's charges, made during the Court-packing fight, of maladministration in the federal courts generally. ${ }^{21}$

Diffusion of responsibility for administration in these courts not only accorded with Hughes' belief in the principles of federalism and with his desire to shield the High Court from politically-inspired attacks in the future, but such diffusion enjoyed the support of Congressman Hatton Sumners, the powerful chairman of the House Judiciary Committee. ${ }^{22}$

As first proposed by Hughes, each circuit council was to be staffed by an administrative officer and have "direct control" of its budget ${ }^{23}$ as well as to be charged with gathering statistical information. ${ }^{24}$ Judge Parker vigorously objected to this focus on the councils as complete administrative units, and ultimately budgetary and statistical duties would be housed in the Washington-based Administrative Office of the United States Courts. ${ }^{25}$

Nevertheless, the councils became repositories of vast responsibilities. Section 306 of the Act of August 7, $1939^{26}$ vested in the several councils of circuit judges responsibility for insuring the effective and expeditious transaction of district court business and required "the district judges promptly to carry out the directions of the council as to the administration of the business of their respective courts."

This statutory language which became section 332 of title 28 of the United States Code indicated a broad grant of power. And at the hearings, judges acknowledged this intent. "Do you put any restraint on the council at all?" inquired Congressman Emanuel Celler. Replied Judge John J. Parker: "I do not think this bill does." ${ }^{27}$ Hughes, too,

21 See 6 The Public Papers and Addresses of Franklin D. Roosevelt 52 (S. Rosenman ed. 1937); Hearings on the General Subject of the Administration of the Federal Courts Before a Subcomm. of the House Comm. on the Judiciary, 75th Cong., 3d Sess. 44 (1938) (stenographic transcript on file in National Archives under H.R. 2973, 75th Cong., 3d Sess. (1938)).

22 Letter from Hatton W. Sumners to Burke Shartel, March 10, 1937 (on file in the National Archives under H.R. 2271, 75th Cong., Ist Sess. (1937)).

23 Administration in the Federal Courts at 16-17.

24 Letter from D. Lawrence Groner to John J. Parker, November 30, 1938, Duncan Lawrence Groner Papers (Box 21, Alderman Library, University of Virginia, Charlottesville, Virginia) [letters in the Duncan Lawrence Groner Papers will be hereinafter cited as Groner Papers].

25 Groner Papers, Box 4 (John J. Parker to D. Lawrence Groner, Dec. 1, 1938).

2653 Stat. 1224, 28 U.S.C. § 332 (1964).

27 Hearings on H.R. 2973, H.R. 5999 Before the House Comm. on the Judiciary, 76th Cong., Ist Sess., 22 (1939) [hereinafter cited as Hearings on H.R. 2973]. 
thought the councils were empowered to "see that any necessary steps are taken to correct procedural defects and to expedite the work of the courts." 28

In the eyes of ranking federal judges who had participated in the drafting of section 306, a multitude of administrative functions lay within the competence of the councils. These tasks included: assigning judges to congested districts, ${ }^{29}$ and to particular types of cases, ${ }^{30}$ directing them to assist infirm judges, ${ }^{31}$ ordering them to decide cases long held under advisement, ${ }^{32}$ requiring a judge to forego his summer vacation in order to clear his congested docket, ${ }^{33}$ compelling multi-judge courts to arrange staggered vacations, ${ }^{34}$ and setting standards of judicial ethics. $^{35}$

Although wide agreement existed on the scope of the councils' powers, judges differed over the manner of exercising this power and over the degree of permitted coercion. Opposing conceptions of the councils' actual authority as distinguished from their legal powers involved different conceptions of the composition of these circuit organs. On one side stood administrative activists who favored single-member councils; on the other were passivists who supported councils with broad-based memberships.

To the activists, the statutory grant of power was clear and the only remaining problem was to centralize responsibility and authority in a single judge, thereby promoting maximum effectiveness and, of course, lodging complete administrative power in the hands of the presiding judges of the appellate courts. Martin Manton of the Second Circuit was of this frame of mind. He assailed any attempt to dilute the unrestricted power of the senior circuit judge to assign district judges, or in his own case, himself, to the district courts. ${ }^{36}$ The corrupt and soon-to-be convicted Senior Circuit Judge demanded that "provision should be made for obedience by all judges of the district courts to any assignment made by the senior circuit judge as well as to ...

28 Address of the Honorable Charles Evans Hughes, 17 ALI Proceedings 27, 31 (1940).

29 Hearings on H.R. 2973 at 21 (statement of John J. Parker). See also Hearings on S. 188 Before the Senate Comm. on the Judiciary, 76th Cong., lst Sess. 18 (1989) (statement of Arthur $T$. Vanderbilt) [hereinafter cited as Hearings on S. 188].

30 Senior Judges Plan to Integrate Federal System, 22 J. AM. Jud. Soc'y. 160, 161 (1938) (inserted by D. Lawrence Groner in Hearings on $S .188$ at 48).

31 Hearings on H.R. 2973 at 11 (statement of D. Lawrence Groner).

32 Id. at 13.

33 Id. at $14,18$.

$34 \mathrm{Id}$. at 18 .

35 Id, at $18,53-54$.

30 See Chandler, Some Major Advances in the Federal Judicial System: 1922-1947 31 F.R.D. 307, 380 (1963) [hereinafter cited as Chandler]; see also Groner Papers, Box 4 (Martin T. Manton to D. Lawrence Groner, Dec. 13, 1938). 
his directions as to the conduct of business of their respective courts." 37

Manton did not act alone. He drew support from others on the Judicial Conference who regarded the Administrative Office Bill as "an efficiency measure," 38 and who like Judge Parker feared that a multi-judge council would constitute "a mere "fifth wheel to the coach" " breeding more confusion than responsible action. ${ }^{39}$

Chief Justice Hughes' influence proved decisive, and he favored multi-judge councils. ${ }^{40}$ "It would be very unwise to impose upon the Senior Circuit Judge all of the corrective power over District Judges," Hughes argued,41 because, as one of his Conference allies observed, such an organization would exacerbate the serious problems associated with one-man control, namely physical or mental incapacity, indifference, or dictatorial attitudes. ${ }^{42}$

Perhaps even more compelling was the Chief's singular perception of the kind of authority available to the councils. Under administrative supervision by the several circuit judges, Hughes believed "the district judges would not feel that they were dependent upon ... a particular circuit judge, and . . . would feel their requests had consideration of the organization in the circuit." 43 A multi-judge council, he told Chief Justice D. Lawrence Groner of the Court of Appeals for the District of Columbia Circuit, would promote "greater confidence on the part of the bar and public" than would a single-judge organ. ${ }^{44}$ And its authority would be perceived as legitimate by trial and appellate judges alike. ${ }^{45}$

This emphasis upon the composition of the responsible administrative agency acknowledged the nature of authority in the judiciary. As members of a professional guild, with its own process of socialization and with its own recognized standards of conduct and ways of doing

37 Groner Papers, Box 4 (Martin T. Manton to D. Lawrence Groner, Oct. 24, 1938).

38 Id. (Evan A. Evans to D. Lawrence Groner, Nov. 17, 1938).

39 Id. (John J. Parker to D. Lawrence Groner, Dec. 1, 1938).

40 Administration in the Federal Courts at 15-16, 18.

41 Groner Papers, Box 4 (D. Lawrence Groner to Senior Circuit Judges, Dec. 21, 1938).

42 Id. (Suggestions of Judge [Kimbrough] Stone, Oct. 14, 1938).

43 Chandler 380.

44 Groner Papers, Box 21 (D. Lawrence Groner to John J. Parker, Nov. 30, 1938). The presiding judge of the United States Court of Appeals for the District of Columbia Circuit was designated "chief justice" by the Act of February 9, 1893, 27 Stat. 434. By the Act of June 25, 1948, 62 Stat. 991, his designation became "chief judge," as did that of all "senior" circuit and district judges.

45 Administration in the Federal Courts at 16. In the event trial judges challenged council legitimacy on grounds that district judges lacked representation on the councils, Hughes and Groner believed the council composition could and should be altered to include such representation. See Groner Papers, Box 21 (D. Lawrence Groner to John J. Parker, Nov. 30, 1938). See also Chandler 385. 
things, judges accepted as legitimate those actions resting on acceptable premises. After all, said one senior circuit judge, "we are not dealing with plumbers or ditch diggers when we are dealing with Federal judges." 46 With such individuals, unabashed exercises of administrative power were not only unacceptable, but, hopefully, unnecessary.

Confidence in voluntary compliance was widely expressed at the time of the council's establishment. Judge Groner found it hard to conceive of a district judge's refusal to follow the admonitions of the appellate judges. ${ }^{47}$ So did Parker. He would later assert that "you don't have to threaten judges to get them to carry out the directions of the councils; they carry them out because the judges are good men, they want to do what is right. . .." 48

In any case, the councils were not expected to make impossible demands on the trial judges. "Except in mere routine," stated Groner, "the authority will be utilized very infrequently." 49 It was not its use, but its mere existence, which, Judge Parker thought, would foster improved administration in the federal court system. ${ }^{50}$

Whenever the councils did invoke their compulsory power, the framers of the Act of 1939 had a definite conception of the means at their disposal. Coercion, Judge Groner had told the House Committee on the Judiciary, unquestionably constituted the object of the Administrative Office Bill. ${ }^{51} \mathrm{He}$ offered a short list of instruments for achieving such coercion. Consultation, reasoned arguments and persuasion, and publicity, but not penal sanctions, loomed large in his mind. "More perhaps can be done by a diplomatic handling of a bad situation where cooperation of the district judges is necessary than by coercion under authority of law," observed his counterpart from the Seventh Gircuit, Evan A. Evans. ${ }^{.2}$

"Just turning the light of day on the judges probably in most instances would be all that is required." 33 Peer-group ostracism would do the rest.

Sanctions more dramatic than these were never contemplated by the judges. ${ }^{54}$ "There may be instances you cannot cure at all," remarked

46 Groner Papers, Box 4 (Evan A. Evans to D. Lawrence Groner, Nov. 17, 1988).

47 Hearings on H.R. 2973 at 14 (statement of D. Lawrence Gronex).

48 Hearings on H.R. 4394 Before a Special Subcomm. on Bankruptcy and Reorganization of the House Comm. on the Judiciary, 77th Cong., 1st Sess. 92 (1941) (statement of John J. Parker) [hereinafter cited as Hearings on H.R. 4394].

49 Groner Papers, Box 4 (D. Lawrence Groner to Senior Circuit Judges, Dec. 21, 1938).

50 Hearings on H.R. 4394 at 91-92.

51 Hearings on H.R. 2973 at 15 (statement of D. Lawrence Groner).

52 Groner Papers, Box 4 (Evan A. Evans to D. Lawrence Groner, Nov. 17, 1938).

53 Chandler 382.

54 Hearings on H.R. 2973 at 22 (statement of John J. Parker). 
Senior Circuit Judge Orie Phillips, “but I don't believe you can do it by force." 55 Positive sanctions were for Congress to apply; but no augmentation of that body's power accompanied the reform of 1939. As it had since 1789, Congress possessed only the unwieldy impeachment power.

\section{Council Organization and Procedures}

In the years since enactment of the Administrative Office Bill of 1939, circuit council organization has changed little from that envisioned and secured by the Act's judicial framers. Committees of the councils have, however, emerged with the increase in appellate judgeships and the need for greater specialization. ${ }^{50}$ "Whenever a problem comes up at one of the ... meetings of our Judicial Council in which inquiry must be made," Judge Carl McGowan of the Court of Appeals for the District of Columbia Circuit stated, "our only resource, and our invariable practice, is to appoint an ad hoc committee of two or three judges to look into the matter and make recommendations to the Council for action." ${ }^{\prime \prime 7}$ Such committees, like the council itself, lack staffs. Thus the judges themselves must deal with a variety of issues, many of which "are not purely judicial in nature," but which "require legwork and time-consuming conferences with persons outside the judicial circle."58

As for the district judges who have a great stake in policies adopted by the councils, they enjoy access to, if not representation on, the circuit bodies. Councils, through their chief judges, have invited trial judges to attend those portions of their sessions devoted to consideration of legislation affecting the district courts ${ }^{59}$ as well as specific administrative problems confronting the lower tribunals. ${ }^{60}$

More varied than their organization have been the procedures followed by different councils. Required by law to meet twice a year, ${ }^{61}$

55 Chandler 382 .

56 Charles E. Clark Papers, Minutes of the Council of the Second Circuit, Oct. 17, 1957, at I (private papers of Elias Clark, New Haven, Connecticut) [hereinafter cited as Clark Papers]. See also Clark Papers (J. Edward Lumbard to Robert P. Anderson, Nov. 20, 1961); id. (Minutes of the Meeting of the Second Circuit Council, Nov. 4, 1961, at 7).

57 Hearings on S. 3075 at 275.

58 Id.

59 Meeting of the Judicial Council [of the District of Columbia], Friday, April 14, 1952, Harold M. Stephens Papers (Box 221 Library of Congress, Washington, D.C.) [hereinafter cited as Stephens Papers].

60 Clark Papers (Minutes of the Meeting of the Second Circuit Council, Oct. 17, 1957, and Nov. 11, 1959). See H.R. REport No. 201, at 10, urging chief judges of the courts of appeals to invite "the district judge, who is the representative on the Judicial Conference of the United States, to attend a council meeting."

6128 U.C.C. \$ 332 (1964). 
some meet monthly, ${ }^{62}$ while that in the Ninth Circuit has met an average of eight times a year since $1955 .{ }^{83}$ In the District of Columbia Circuit, however, no councils had ever been formally convened nearly five years after enactment of the statute. ${ }^{64}$ Chief Justice Groner simply "considered that the Council of this Circuit was in perpetual session and that any matter affecting the work of the Judges of the District Court known to any member of the Council would be brought to the attention of the other members." 65 His successors, however, have held monthly meetings. ${ }^{66}$ In circuits less compact than the District of Columbia, the geographical dispersion of judges and the infrequency of en banc proceedings militate against many formal council sessions. ${ }^{67}$ Here telephone communications partially fill the void. ${ }^{68}$

Councils differ, too, in their maintenance of records. The Third Circuit has long maintained detailed minutes of its sessions, copies of which are filed with the Administrative Office, ${ }^{69}$ but the Second's records are little more than amplified agendas. ${ }^{70}$

As with records, so with the entire decision-making process. In some circuits the process is highly formal; in others, quite the contrary. By law, circuit council approval is required for routine changes in the numbers, territories, and salaries of bankruptcy referees. ${ }^{71}$ In the Third Circuit, the council formally polls its members on such issues, ${ }^{72}$ while that in the Second has operated much more informally. "I "I assume each member of our Judicial Council is in agreement with the recommendation of the Administrative Office," wrote Chief Judge Sterry Waterman to his colleagues, "and, though there is some doubt as to the effect of a vote of only three of us in a court of six (II) I will take your vote as sufficient authority to support the recommendations." "74

62 Interview with Albert B. Maris, in Philadelphia, Pa., Dec. 29, 1964.

63 Letter from Richard H. Chambers to Olin D. Johnston, June 20, 1961, on file with the Subcomm. on Improvements in Judicial Machinery of the Senate Comm. on the Judiciary (file on H.R. 6690, 87th Cong., 2d Sess. (1962)).

64 Stephens Papers, Box 28 (Justin Miller to D. Lawrence Groner, Jan. 27, 1944).

65 Groner Papers, Box 13 (D. Lawrence Groner to Justin Miller, Jan. 28, 1944).

66 Prettyman, The Duties of a Circuit Chief Judge, 46 A.B.A.J. 633, 634 (1960); Hearings on S. 3055 at 275 (statement of Carl McGowan).

67 Letter from Olin D. Johnston to Richard H. Chambers, undated (1961), supra note 63.

68 Interview with Simon Sobeloff in Baltimore, Md., Jan. 18, 1965.

69 FIELd STUdY OF THE OpERATIONS OF UNITED STATES CourTs, supta note 8, at 57.

70 See Clark Papers (Minutes of the Meeting of the Circuit Council, Nov. 15, 1951).

7111 U.S.C. $\$ \$ 65,68,71$ (1964).

72 Interview with Albert B. Maris, supra note 62.

73 Clark Papers (Sterry R. Waterman to Warren Olney, III, Feb. 17, 1960).

74 Clark Papers (Sterry R. Waterman to Charles E. Clark and Judges of the United States Court of Appeals for the Second Circuit, June 29, 1961). 


\section{The Functions of the Crrcuit Councils}

\section{A. Glearing-House Functions}

As administrative linchpins of the federal judiciary, council functions approximate those of most administrative organizations. A primary council task since the 1940's has been that of clearing for subsequent consideration by the Judicial Conference proposed administrative and legislative policies, particularly those relating to the district courts within the circuits of the respective councils. ${ }^{75}$ Proposals from these courts are'screened by the councils, and if approved, submitted to Congress, or more likely, to the Judicial Conference or one of its numerous committees. ${ }^{76}$ Negative use of this power is not unknown, and, in the Ninth Circuit under Chief Judge William Denman, council vetoes of district judge and circuit conference recommendations were a thing to be reckoned with. ${ }^{77}$

The bulk of this clearing-house business typically involves lower court requests for more money and manpower. ${ }^{78}$ However, since the early 1950's, requests for additional judgeships have travelled the council route on their way to the Judicial Conference, ${ }^{79}$ as has pending legislation affecting intra-circuit judicial administration. The ability of the councils to act promptly and the wholly circuit-related nature of some legislation encouraged the 1961 Judicial Conference to direct

that any bill to create a new judicial district, to establish a new division within any existing judicial district, to authorize a new place for holding federal court, or to waive the provision of 28 U.S.G. 142 respecting the furnishing of accommodations at places of holding court be submitted . . . first to the Judicial Council of the Gircuit involved for its consideration and recommendation which shall then be transmitted by the Director to the Committee on Court Administration for its consideration and report to the Judicial Conference. ${ }^{80}$

Issues of greater complexity and of national rather than regional importance also pass through the councils and may in fact arise there. Making its way in the late 1950's from the Third Circuit's council

75 Cf. 1940 Judicial CONFERENCE REPORT 33.

76 See 1962 Judicial CONFERENCE REPORT 48.

77 See Stephens Papers, Box 233 (excerpt from Proceedings of the Conference of Judges and Lawyer Delegates of the Ninth Judicial Gircuit, July 1954, at 73-74, 254).

78 Clark Papers (Agenda, Second Circuit Council, May 19, 1962).

79 See 1952 Judicial Conference Report 21. See also Henry P. Chandler, Standards for Creation of New District Judgeships, Sixth Circuit Judicial Council, April 17, 1953, Correspondence of the Administrative Office of the United States Courts, 59-A-532 (Box 1, Federal Records Center, Alexandria, Virginia) [such correspondence will hereinafter be referred to as Administrative Office Correspondence].

801961 JUdicial CONFERENCE REPORT 66. 
was a question of the power of retired judges on assignment to participate in the adoption of rules of court, the appointment of officers, and similar functions of the court sitting en banc. This issue "had been raised in other circuits," the chief judge of one district court in the circuit informed his council, "and . . . the views of the Judicial Conference of the United States upon the subject would be most helpful." The council agreed and authorized its chief judge "to suggest to the Committees on Court Administration and Revision of the Laws of the Judicial Conference of the United States that they study the problem and, if they think it appropriate, to report upon it to the next session of the Judicial Conference." 81

\section{B. Scope of Intra-Circuit Functions}

Although the councils are clearly a cog in the larger policy-making process, their importance stems less from this role than from their legal responsibility for the "administration of the business of the courts within its [sic] circuit." 82 This language, inserted during the 1948 revision of the Judicial Code, modified that contained in the Administrative Office Act. ${ }^{83}$ Framers of the Act had clearly contemplated council supervision of district court administration, but had left vague its role in administering the courts of appeals. The 1948 revision resolved the uncertainty at least by implication..$^{84}$

However the statutory language may be construed, councils have, in fact, often used their sessions to discuss and settle judicial and administrative problems wholly confined to the appellate court. They have considered cases, ${ }^{85}$ drafted per curiam opinions, ${ }^{86}$ settled summer schedules, ${ }^{87}$ considered circuit court housing and personnel as well as proposed changes in the rules of the court of appeals, ${ }^{88}$ and designated the purposes for which the fees collected from attorneys admitted to the appellate court bar may be used. ${ }^{89}$

81 Minutes of 119th Meeting of the Judicial Council of the Third Circuit, June II, 1958, Administrative Office Correspondence, 60-A-427, Box 101.

8228 U.S.C. § 332 (1964).

83 See id.

84 H.R. REP. No. 201, at 2. But see Hearings on Judicial Fitness Before Subcomm. on Improvements in Judicial Machinery of the Senate Comm. on the Judiciary, 89th Cong., 2d Sess., pt. 7, at 12 (1966) [hereinafter cited as Hearings on Judicial Fitness].

85 Clark Papers (Minutes of the Meeting of the Second Circuit Council, Nov. 11, 1959). 86 Id.

87 Stephens Papers, Box 88 (Memorandum Concerning Summer Schedules, June 27, 1951).

88 Clark Papers (Agenda of the Circuit Council of the Second Circuit, May 9, 1962); Clark Papers (Minutes of the Circuit Council of the Second Circuit, at 8, Nov. 4, 1961).

89 See 4TH CIR. R. 6; 6TH CIR. R. 6; 8TH CIR. R. 6; 9TH CIR. R. 11. This rule requires the court clerk to disburse revenue from fees on order of the chief judge "pursuant to resolutions of the court prescribing the purposes for which such funds may be disbursed." 
The annual circuit judicial conferences have increasingly claimed the attention of councils which have come to serve as the organizing agency for the meetings. This role was especially pronounced in the Second Circuit when Chief Judge Charles E. Clark sought to overhaul that circuit's moribund conference. Not only did the council continue to fix agenda topics as it had in the past, ${ }^{90}$ but it also created and appointed a committee of lawyers to execute the program. ${ }^{91}$

In some circuits, the council's role has been formalized in a rule of court. Rule 20(a) of the Court of Appeals for the District of Columbia Circuit requires that the full council approve the lawyer members named to the committee on Conference Arrangements as well as "the proposed agenda of the public session of the Conference."92 Rules of court in the Second and Third Circuits likewise provide for council participation in the selection of either the members of the Planning and Program Committee of the Judicial Conference in the former circuit ${ }^{93}$ or the lawyer-delegates to be designated "life members of the conference" in the Third. ${ }^{94}$

Unlike other circuit councils, that in the District of Columbia enjoys formal authority to take the initiative in appointing committees to report to the Judicial Conference "on matters pertaining to the improvement of the administration of justice within the circuit."95

But as perceived by the framers of the Administrative Office Act, the critical work of the councils was their responsibility for effective and expeditious administration of the business in each district court within their circuits. ${ }^{96}$ And in this realm, their mandate was sweeping. It meant

not merely ... dealing with the question of the handling and dispatching of a trial court's business in its technical sense, but also ... dealing with the business of the judiciary in its broader or institutional sense, such as preventing . . . any stigma, disrepute, or other element of loss of public confidence occurring as to the Federal courts or to the administration of justice by them, from any nature of action by an individual judge or a person attached to the courts. ${ }^{97}$

90 See Clark Papers (Minutes of the Circuit Council, Nov. 15, 1961). See also Stephens Papers, Box 88 (Harold M. Stephens to Joseph Stewart, Oct. 18, 1951).

91 Clark Papers (Minutes of the Second Circuit Council, Oct. 15, 1959).

92 D.C. CIR. R. 20(a).

93 2ND CIR. R. 22(4).

94 3RD CrR. R. 15(3)(g). Rule 15(4) permits the council to fix the registration fee for all members attending sessions of the Judicial Conference.

95 D.C. CrR. R. (20)(d).

9628 U.S.C. $\S 332$ (1964).

97 H.R. RE. No. 201 , at 7. 
Council jurisdiction is broad, but it does not extend to the legality of judicial conduct" ${ }^{98}$ nor does it encompass "the legal correctness of the work of the respective district courts." 99 Nevertheless, its jurisdiction is sufficiently extensive that the councils constitute a potentially significant integrative element within the diffused federal judiciary, albeit integration on a regional rather than a national scale.

\section{Statutory Functions}

The integrative role of the councils assumes importance in the light of the twentieth century proclivity of Congress to delegate to the judiciary powers once regarded as wholly within the legislative prerogative. And among the recipients of these grants of power have been the councils. The powers so delegated typically require that the councils either review administrative decisions made in the first instance by district judges or resolve disagreements among trial judges.

The councils' utility as instruments of integration became apparent when district judges sought general legislation enabling them to fix the time and place of holding court and to abolish places of court by a simple rule of the district court. This change would clearly have placed a major area of administration in the "uncontrolled discretion of the district judges." 100 To a committee of the Judicial Conference, the councils "should logically have a voice in the matter."101 Alterations made by rule of court should pass muster with the relevant council thereby insuring that "proposed changes be given consideration from a wider point of view."'102

Congressional grants of specific powers to the councils reflect this desire to render the district judges responsible to a less parochial authority. Councils must consent to pretermission by the district courts of any terms of court, ${ }^{103}$ and under the Bankruptcy Act, the councils

98 When a council uncovers illegal conduct, it may, by resolution, call on the Department of Justice for an investigation and notify the House and Senate Judiciary Committees of the existence of grounds for impeachment. See Hearings on Judicial Fitness at 19 (statement of John Biggs, Jr.); Letter from Henry P. Chandler to Senior Circuit Judges, Sept. 3, 1942, on file in Administrative Office of the United States Courts, Washington, D.C.

99 The Judicial Council of the Third Circuit: In the Matter of the Examination by the Administrative Office of the United States Courts of the Records of Everett G. Rodebaugh, one of the Court Reporters of the United States District Court for the Eastern District of Pennsylvania, 10 F.R.D. 207, 215 (1951) [hereinafter cited as The Judicial Council of the Third Circuit].

100 Administrative Office of the United States Courts, Report of the Committee on Ways and Means of Economy in the Operation of the Federal Courts as Amended by the Judicial Conference of the United States, Sept. 1, 1948.

$101 \mathrm{Id}$.

102 Id. at 3. See 1948 JUdIGIAL CONFERENCE REPORT 34.

10328 U.S.C. \& 140(a) (1964). 
as well as the district judges must pass on recommendations of the director of the Administrative Office for changes in the number, territories, and salaries of referees; these are then submitted to the Judicial Conference for final determination. ${ }^{104}$

The Federal Magistrates Act of $1968,{ }^{105}$ which abolished the historic commissioner system characterized by many non-lawyer office-holders and a fee system, ${ }^{106}$ largely followed the pattern established by the Bankruptcy Act. Under its terms, the director, the district courts, and the circuit councils all make recommendations to the Judicial Conference on the number and salaries of full-time and part-time magistrates, the Conference then acting in the light of these recommendations. ${ }^{107}$

Both the Criminal Justice Act of $1964^{108}$ and the Jury Selection and Service Act of $1968^{109}$ provide for the traditional council review function. Councils must pass on and approve, under the Criminal Justice Act, district court plans "for furnishing representation for defendants charged with felonies or misdemeanors ... who are financially unable to obtain an adequate defense,"110 while under the Jury Selection Act they must similarly act on trial court plans "for random selection of grand and petit jurors." 111 Present and participating with the council is "either the chief judge of the district court whose plan is being reviewed or such other active district judge of that district as the chief judge may designate."112 His presence is intended "to insure that any special considerations underlying particular features of the district court's plan will be given adequate weight by the reviewing panel."113

Circuit councils have been formally designated as arbiters of disagreements over administrative policies in the lower courts. If the trial

10411 U.S.C. $\$ \S 65(b)(1), 68(a), 68(b), 71(b), 71(c)$ (1964). However, a vacancy in the office of referee may be filled, if no changes are made in salary or other arrangements, when recommended by the director, the district judge or judges, and the circuit council without a recommendation to the Judicial Conference or its approval. 11 U.S.C. $\S 71(\mathrm{~b})$ (1964).

10528 U.S.C. § 631, as amended by P.L. 90-578, 82 Stat. 1107 (1968).

106 See H.R. REP. No. 1629, 90th Cong., 2d Sess. 13-14 (1968).

10728 U.S.C. \& 633(b) (1964).

10878 Stat. 552, 18 U.S.C. \$ 3006 A (1964).

10928 U.S.C. $\S 1861$, as amended by P.I. 90-274, 82 Stat. 54 (1968).

11018 U.S.C. \& $3006 \mathrm{~A}$ (a) (1964).

11128 U.S.C. § 1863(a) (1964).

112 Id.

113113 Cong. REc. 35633 (1967). It should be noted that the Jury Act limits review to the issue of the district court plan's compliance with the provisions of the statutes, 28 U.S.C. $\S 1863(a)$ (1964). "It is not intended," the House Judiciary Committee declared, "that the [reviewing] panel should be able to substitute its own plan for the district court's if the district court's plan complies with the statute." See H.R. REP. No. 1076, 90th Cong., 2d Sess. 9 (1968). 
judges "are unable to agree upon the adoption of rules or orders for [dividing the district's business among themselves] the judicial council of the circuit shall make the necessary orders."114 Provisions of the Bankruptcy Act likewise provide for council intervention whenever the judges of a district court fail to achieve a meeting of the minds. Such a failure in designating a referee to fill a vacancy in another referee's office may lead to council action ${ }^{115}$ as would an inability on the part of the trial judges to agree on the removal of a referee for cause. ${ }^{116}$ Similarly, the Federal Magistrates Act of 1968 permits a majority of all judges on the circuit council to remove a magistrate whenever there exists a tie vote among the district judges on the question of removing or retaining that officer. ${ }^{117}$

As collegial bodies in which responsibility for any given decision is diffused among a dozen or more judges, the councils offer a ready vehicle for dealing with such sensitive issues as judicial assignments and work capacity. Judges and Congressmen have recognized this legitimizing function by carving out a role for the councils in the assignment of judges, a realm largely subject to the prerogatives of the chief circuit judge. 118 "Any retired circuit or district judge," reads the law, "may be designated and assigned by the chief judge or judicial council of his circuit to perform such judicial duties within the circuit as he is willing and able to undertake."119 One or the other must also consent to the designation and assignment of an active judge from one circuit to another. ${ }^{120}$ This ratification role has been extended to include the intercircuit transfer of other court officials such as referees in bankruptcy. ${ }^{121}$

Whenever special circumstances arise, chief judges tend to invoke the prestige of the councils rather than act on their own. "These designations," declared Senior Circuit Judge John J. Parker, "in . . . unusual cases are usually made at the suggestion of the council." Rarely would he "make a designation, except a routine designation, unless the council approved or authorized it." ${ }^{122}$

\footnotetext{
11428 U.S.C. § 137 (1964).

11511 U.S.C. \& 71(c) (1964).

11611 U.S.C. \& 62(b) (1964).

11728 U.S.C. $\$ 631(\mathrm{~h})(1964)$.

11828 U.S.C. §§ 291(a)-(c), §§ 292(a)-(c), § 295; see Hearings on S. 3055 at 266 (statement of $\mathrm{J}$. Edward Lumbard).

11028 U.S.C. $\$ 294$ (c) (1964).

12028 U.S.C. \& 295 (1964).

121 The Bankruptcy Act as amended by the Act of September 19, 1959, 64 Stat. 866, requires that the chief judge or the circuit council of the circuit from which a referee in bankruptcy is designated and assigned consent to his designation and assignment to another circuit. II U.S.C. $\$ 71$ (c) (1964).

122 Hearings on $S$. 1051 at 45 . The practice of council assignment as distinguished
} 
In the same category lies the cancellation of a proud and sensitive, but perhaps physically and/or mentally enfeebled, retired judge's assignment. ${ }^{123}$ So, too, refusal of a request for intercircuit assignment of active trial judges would likely find a chief judge seeking his council's endorsement. "Naturally reluctant to decline to approve the proposed transfer," Chief Judge Harold Stephens of the District of Columbia Circuit wrote his counterpart in the Ninth Gircuit, "I not only gave the request consideration myself, but also, . . . to make sure that my own attitude was not erroneous, placed the matter ... before the Council."'124

Since the Vinson era, various statutes have empowered the councils to take positive action without awaiting initial action by or disagreement among the trial judges or a waiver of his prerogatives by the chief circuit judge. For instance, in the wake of a controversy over maintenance expenses in the early 1950's, ${ }^{125}$ Congress empowered the councils "to direct a judge to maintain his abode at or near a particular place of holding court within his district."128

Several years later, it further strengthened the councils' hands in the realm of judicial behavior by authorizing a majority of their members to certify the permanent mental or physical disability of district and circuit judges who, though eligible to retire, refuse to step down. Thereafter, the President may appoint an additional judge in the usual fashion if he agrees with the council's findings and determines that an additional judge is "necessary for the efficient dispatch of business." The disabled judge, should he remain on the bench, then becomes "junior in commission" and hence less capable of impeding or disrupting his court's administrative and judicial work. ${ }^{127}$

\section{Quasi-Legislative and Executive Functions}

The specific statutory powers given the councils describe only a part, and a minute part at that, of the actual scope of the councils' work. Under section 332, they consider a broad range of subjects which may not involve application of the explicit grants found elsewhere in the Judicial Code. In fact the specific grants of power provided the coun-

from that of the chief judge varies. See letter from Richard $H$. Chambers to Olin $D$. Johnston, June 20, 1961, supra note 63.

123 Letter from Richard H. Chambers to Olin D. Johnston, Dec. 21, 1961, supra note 63. See also 28 U.S.C. \$ 294(e) (1964).

124 Stephens Papers, Box 90 (Harold M. Stephens to William Denman, May 21, 1954). 125 See 1953 Judicial CONFERENCE REPORT 239-340.

12668 Stat. 12; see 28 U.S.C. $\$ 134$ (c) (1964).

12728 U.S.C. § 372(b) (1964). 
cils by the Bankruptcy, Magistrates, Criminal Justice, and Jury Selection Acts may well be redundant.

As the House Committee Report on the Jury Act observed:

[T] he approval provision in the proposed statute . . . only make[s] clear the scope of the power that the judicial councils pursuant to section 332 already have to modify or approve local plans. . . . Presumably, this authority embraces jury selection procedures as well as other matters of judicial administration. ${ }^{128}$

Utilizing section 332 powers, councils may pass on issues running the gamut from decisions on the most mundane housekeeping details to critical cases of judicial misbehavior on which the judiciary's reputation hangs.

The councils can become veritable receptacles for trivial issues chiefly of a housekeeping nature. One meeting in the Second Circuit found Chief Gircuit Judge Charles E. Clark reporting on a proposal to grace the barren walls of the old Federal Courthouse in Foley Square with portraits of former luminaries of the bench and bar. The portrait hanging, however, generated surprising opposition among the district judges, perhaps because the suggestion had originated with several circuit judges. Thus Clark stated that "[n]o action was taken, as the lack of enthusiasm seemed somewhat contagious."128

A major function of the circuit councils lies in their supervision of the flow of judicial business in the trial courts. Prodded by the Judicial Conference for action on backlogs of cases, ${ }^{130}$ and by the data contained in quarterly reports from the Administrative Office, ${ }^{131}$ they are expected to respond to any problems so revealed. In the wake of one such report, a session of the Second Circuit's council discussed at length

the continuing chaotic congestion in the Eastern District of New York and the lack of calendar control or administrative direction there existing, resulting in its being the district of worst delay in the country according to the report of the Administrative Director. ${ }^{132}$

128 H.R. REP. No. 1076, 90th Cong., 2d Sess. 9 (1968).

129 Clark Papers (Minutes of the Judicial Council, Second Circuit, Oct. 15, 1958).

1301961 JUDICIAL CONFERENCE REPORT 63.

13128 U.S.C. $\S 332$ (1964). See also Minutes of the 119th Meeting of the Judicial Council of the Third Circuit, June 11, 1958, Administrative Office Correspondence, 60-A-427, Box 101.

132 Clark Papers (Minutes of the Meeting of the Second Circuit Council, Nov. 15, 1956, at 4). 
The councils, as Chief Justice Earl Warren stated in his 1968 address to the American Law Institute, "have had their responsibilities substantially increased with actual managerial responsibilities. . . ."133 Both the Criminal Justice Act and the Jury Selection Act impose on the councils continuing supervisory functions which cannot be avoided. Not only must they initially review district court plans and modifications thereof, ${ }^{134}$ but also council scrutiny of the manner in which the plans are executed is required. The Criminal Justice Act of 1964 provides that each district court and circuit council "shall submit a report on the appointment of counsel within its jurisdiction to the Administrative Office of the United States Courts. . . ."135 Similarly, the Jury Act requires that the councils receive the names of all persons excluded from jury service "together with detailed explanations for the exclusions." 136 It is then empowered "to make any appropriate order, prospective or retroactive to redress any misapplication" of the statutory. classifications. ${ }^{137}$

\section{E. Quasi-Judicial and Executive Functions}

The broad powers enjoyed by the councils over "the business of the courts" have sometimes blurred the distinction between administrative and purely judicial functions. Thus councils have considered the exclusion of an interested party from a trial and a lawyer's right to appear in a case. ${ }^{138}$ In a more narrow sense, councils have acted in their quasijudicial capacity in matters which are more clearly administrative. "The council is the administrative agency empowered by Congress to investigate and determine the facts and fashion the appropriate remedy," stated the Third Circuit council in a leading case. ${ }^{139}$ This had been a role promoted by Chief Justice Hughes and one which, in the words of the first director of the Administrative Office, Henry P. Chandler, "could put to rest many complaints that, if there is no way of dealing with them within the judicial system, are likely to be handled in a way which is much less considerate of the courts."140

Early constructions of council power to entertain, much less act on,

133 Reprinted in Hearings on S. 3055 at 297.

13418 U.S.C. $\S 3006 \mathrm{~A}(\mathrm{a})$ (1964); 28 U.S.C. § 1866(a) (1964).

13518 U.S.C. $\$ 3006 \mathrm{~A}(\mathrm{~g})(1964)$.

13628 U.S.C. \$ $1866(c)$ (1964).

137 Id.

138 Administrative Office of the United States Courts, Memorandum on the Powers of the Judicial Councils (July 13, 1949) (app. A) [hereinafter cited as Memorandum on the Powers of the Judicial Councils].

139 The Judicial Council of the Third Circuit, supra note 99, at 216.

140 Letter from Henry P. Chandler to Kimbrough Stone, January 3, 1941, Administrative Office Correspondence, 57-A-122, Box 2. 
such complaints were restrictive, ${ }^{141}$ but this interpretation was gradually eroded. By the 1950's council jurisdiction over alleged untoward conduct had won wide acceptance. ${ }^{142}$

Although only occasionally called upon to review "cases of malfeasance of a judge who is able and willing but refuses to do the things he should do," 143 councils have often found themselves confronted with the more common problems of "advancing age, with its accompanying advance in senility, lack of mental powers, and alcoholism."144 They have also been faced with such shortcomings as the failure of district judges to appear at conferences for newly appointed judges, ${ }^{145}$ habitual failure on their part to submit to the Administrative Office reports on pending cases, ${ }^{146}$ and their misclassification of court personnel. ${ }^{147}$

Serious charges of unethical and criminal conduct have come before the councils. Thus they have considered a judge's appointment of relatives as court officers, ${ }^{148}$ their practice before him, ${ }^{140}$ as well as cases of outright judicial corruption. ${ }^{150}$ By resolution of the Special Session of the 1969 Judicial Conference, the councils were specifically authorized to review extra-judicial activities of judges for which remuneration was received. When such duties were deemed "in the public interest or ... justified by exceptional circumstances," councils could permit them; otherwise they were prohibited. ${ }^{151}$

Almost as sensitive for the councils are allegations of improper prac-

141 Letter from Kimbrough Stone to Henry P. Chandler, December 18, 1940, Administrative Office Correspondence, 57-A-122, Box 2.

142 See 1956 Judicial CONFERENCE REport 31.

143 Hearings on S. 3055 at 55 (statement of Albert B. Maris).

144 Id.

145 Clark Papers (Minutes of the Meeting of the Second Circuit Council, June 5, 1963, at 4).

146 Minutes of the Meeting of the Committee on Judicial Statistics, March 29, 1946, Administrative Office Correspondence, 60-A-328, Box 4.

1471960 JUdicial CONFERENCE REPORT 9.

148 See letter from Henry P. Chandler to Elmore Whitehurst, Dec. 2, 1940, at 3, Administrative Office Correspondence, 60-A-328, Box 35.

149 Clark Papers (Harvey M. Johnsen to J. Edward Lumbard, Dec. 14, 1960).

150 Hearings on Judicial Fitness, pt. 1, at 18-19 (statements of John Biggs, Jr.). See note 98 supra.

15137 U.S.L.W. 2701 (U.S. June 17, 1969). The November 1969 session of the Judicial Conference suspended the rules relating to extra-judicial activities and financial disclosure adopted the previous June. It also abolished the role of the circuit councils, after these institutions had manifested a congenital defect of a regionalized administrative systemnamely an inability to develop uniform ethical standards. Instead this function was centralized in a "receiving officer" and a three-judge panel appointed by the Chief Justice of the United States and responsible to him and to the Judicial Conference. 38 U.S.L.W. 2271 (U.S. Nov. 11, 1969). 
tices on the part of supporting personnel in the courts. ${ }^{152}$ The refusal of a court reporter to disclose his earnings from a private reporting business for fear it would result in reducing his government compensation and establish a precedent unfavorable to the reporters became a cause celebre in the Third Circuit before being settled by that circuit's council..$^{153}$

Within their wide range of disciplinary jurisdiction, the councils act in the capacity of a conseil d'etat. They do not ordinarily establish the standard of conduct which is one of custom, Judicial Conference resolution, or statutory law, but they do bring the charges, sit in judgment on the case, decide it, and set the penalty. "The usual process," as described by Judge John Biggs,

has been to issue something in the nature of a rule to show cause or a notice to the individual judge who is involved, requesting him or asking him to appear before ... the judicial council with attorneys of his own choosing, so that the matter can be explained to him and so he could be heard.154

If other parties such as the Administrative Office or court personnel are affected, they too are notified and may be represented at the hearing. ${ }^{155}$

As in any proceeding of this nature, the councils may receive testimony and statements presented by the parties. ${ }^{156}$ However, they lack the power of subpoena, a failing which one judge thought "has caused some difficulty in some instances in getting information which ordinarily is not available." 157 But the absence of this power has more subtle consequences for without it councils find it difficult to discipline judges whose relations with litigants and members of the bar are of questionable propriety. "I am sure you appreciate," Chief Judge J. Edward Lumbard told a congressional committee, "the difficulty of getting members of the bar to make a formal complaint or even to communicate to a judicial council what they might know unless there is the power to compel them to give this information."158

152 Interview with Orie L. Phillips in Washington, D.C., Feb. 22, 1965. See 1956 Judrcial CONFERENCE REPORT 31.

153 See letter from Henry P. Chandler to William B. Kirkpatrick, April 5, 1949, Administrative Office Correspondence, 60-A-328, Box 8. See also The Judicial Council of the Third Circuit, supra note 99, at 207-24.

154 Hearings on Judicial Fitness, pt. 1, at 17 (statement of John Biggs, Jr.). See The Judicial Council of the Third Circuit, supra note 99, at 218.

155 The Judicial Council of the Third Circuit, supra note 99, at 218.

156 Id. at 207.

157 Fearings on Judicial Fitness, pt. 1, at 11 (statement of John Biggs, Jr.).

158 Hearings on $S .3055$ at 265. 
Councils may adhere to customary standards of due process but they are under no obligation to do so unless the proceedings involve federal magistrates or referees in bankruptcy. ${ }^{158}$ A Special Session of the Tenth Gircuit's council, meeting in December 1965, felt no such obligation in disciplining the chief judge of the Western District of Oklahoma, Stephen Chandler. It gave him

no notice of the calling of the Special Session or of its purpose, ... no opportunity to be present during the deliberations of the Special Session, no opportunity to hear the nature of any complaint about him, no opportunity to rebut complaints, cross-examine accusers, or present explanations or evidence in his own behalf, and no opportunity to be represented at the Special Session by counsel.

In the words of his attorneys, "he was deprived of liberty and property by secret and summary procedures so shocking that they recall those of the British Star Chamber."161

\section{The Performance of the Circuit Councils}

\section{A. Pillars of Passivity}

Given their broad responsibilities, the councils would seem to constitute veritable "lightning rods" for meeting malfunctions in the federal court system. Their actual performance, however, suggests a contrary view.

At a discussion on judicial administration, held in 1956, Chief Judge Charles E. Clark of the Second Circuit Court of Appeals asked: "How should the circuit council try to push, to stimulate, and to lead the various district courts?"162 From many councils comes the reply: "not very hard." Passivity, not activity, has typically characterized the work of circuit councils. ${ }^{163}$ There exist several reasons for this inert condition.

15028 U.S.C. $\S 631(\mathrm{~h})$ (1964), which closely adheres to the language of 11 U.S.C. $\S 62(\mathrm{~b})$ (1964) respecting referees in bankruptcy, reads: "Before any order or removal shall be entered, a full specification of the charges shall be furnished to the magistrate, and he shall be accorded by the judge or judges of the removing court, courts, council, or councils an opportunity to be heard on the charges." See also Dubnoff v. Goldstein, 385 F. 2d 717, 723 (2nd Cir. 1967).

160 Brief for Petitioner at 10, Chandler v. Judicial Council of the Tenth Circuit, 382 U.S. 1003 (1965) (miscellaneous order).

161 Id. at 17.

162 Clark, The Role of the United States Court of Appeals in Law Administration, 16 CONFERENCE on Judicial ADMinistration 96.

163 See Burger, Courts on Trial: A Call for Action Against Delay, 22 F.R.D. 71, 77 (1958). 
Much depends on the chief judge of the Circuit. Without his leadership, council effectiveness wanes, ${ }^{104}$ and his outright disinterest assures impotence. Such was the situation in the Second Circuit under Senior Circuit Judge Learned Hand. Administrative work, he once said, "I utterly loathe ... and thoroughly despise, as "work for the learned pig,' as John Gray used to say of conveyancing."165 Not every chief judge takes Hand's position, but even so discretion may prove the better part of valor in supervising the work of fellow judges.

Conceived as grass-roots centers of administrative power, the councils' very proximity to the trial courts encourages appellate judges to practice a policy of diplomatic accommodation with the trial judges and, in some instances, this policy is one of formal deference. The judges of the Ninth Circuit's Council have resolved, for example, not "to take any action which might be construed by the district judges as an effort to crack the whip over them."166 As they put it, "schoolmasterish supervision" would entail the loss of "inestimable benefits of a judicial system handled by trial judges who are answerable to no man, and under no control other than that of their own consciences."167 It would foster a "feeling on the part of the judge that he was just another employee taking orders from a judicial council acting as a quasi board of directors."168

This philosophy has been less clearly articulated in other circuits, but nevertheless operative. ${ }^{169}$ It provides the background against which councils have failed to act, especially on problems involving judicial behavior. In this sensitive area, the council in the Ninth Circuit refused to act against judges who charged the government for maintenance expenses of dubious validity, ${ }^{170}$ while that in the Third Circuit defeated outright a proposal to override a district judge's appointment of bailiffs as appraisers in bankruptcy. ${ }^{171}$ Even in so routine a matter as personnel qualifications, councils have refused to infringe upon the district judge's prerogatives in selecting trial court officers. This "hands

164 Interview with J. Edward Lumbard in New York, N.Y., Dec. 30, 1964.

165 Groner Papers, Box $I 1$ (Learned Hand to D. Lawrence Groner, April 5, 1944).

166 Clark Papers (Resolution of the Judicial Council of the Ninth Circuit, Proposed Amendment of Section 332, Title 28, U.S.C., relating to the Judicial Council, Nov. 13, 1959).

167 Id.

$168 I d$.

169 See generally FindD Study of the Operations of United States Courts, supra note 8.

170 Interview with Orie L. Phillips, supra note 152.

171 Interview with J. Edward Lumbard, supra note 164. 
off" attitude was summed up by one former Circuit Chief Judge who asked, "What do the circuit judges know of the man to be appointed?"172

Council inactivity may also be rooted in a pervasive attachment to the ideal of local self-government and an independent judiciary, independent of the remote Judicial Conference, Administrative Office, and Congress. No chief judge defended his colleagues from outside interference more assiduously than did Joseph C. Hutcheson, Jr. of the Fifth Circuit. When the Administrative Office transmitted a petitioner's complaint of delay in one of the districts of his circuit, Hutcheson "objected strenuously" and demanded that it not "follow such a course in reference to his circuit in the future."173 Thereafter, the Office strove mightily to avoid pressing this judge who, in any case, was "inclined to support his judges."174

So, too, the councils provide a formidable defense against congressional demands for reform or economy.175 Their role as "insulators" became evident when word that a district judge in New York City had taken a three-month world tour induced the Senate Appropriations Committee to demand an explanation. 176 "I should think," the former Chief Judge of the Circuit declared, "that this is not an occasion to express public criticism of the judges." In fact, he continued, "we should probably defend a judge's right to a reasonable amount of vacation as against the implications of the Senate inquiry."177 A month later, the judge involved was exonerated.178

For whatever reasons councils or their chief judge remain passive in the face of administrative shortcomings. Inaction has a cumulative effect on the authority of the councils as viable institutions. "Their many failures to act," one critic contends, "have themselves contributed to a feeling on the part of many judges that Section 332 gave the councils no real power; and some judges have thereby been encouraged to defy the councils."'179

172 Interview with Simon Sobeloff, supra note 68.

173 Letter from Leland L. Tolman to Monte M. Lemann, Nov. 3, 1950, Administrative Office Correspondence, $60-\mathrm{A}-328, \mathrm{Box} 4$.

174. Memorandum from Henry P. Chandler to Elmore Whitehurst, June 23, 1955, Administrative Office Correspondence 59-A-48, Box 142.

175 See Clark Papers (Minutes of the Judicial Council of the Second Circuit, June 4, 1959).

176 See Clark Papers (Warren Olney, III to J. Edward Lumbard, Nov. 14, 1960).

177 Id. (Charles E. Clark to J. Edward Lumbard, Nov. 16, 1960).

178 Id. (J. Edward Lumbard to Warren Olney, III, Dec. 20, 1960).

179 Lumbard, The Place of the Federal Judicial Councils in the Administration of the Courts, 47 A.B.A.J. 169, 170 (1961). 


\section{B. Intervention by Higher Authority}

Into the breach thus created has stepped the agency of the more inclusive community, namely the Judicial Conference and its com. mittees. They assume an appellate role when, as Chief Justice Charles Evans Hughes perceived, there exists "any need for the intervention of a central body." 180 That "need" arises in its starkest form whenever councils fail to act on problems well within their jurisdiction.

Highly sensitive issues involving personnel management may paralyze the appellate judges. A district court which wrongly appointed its bailiff as an appraiser in bankruptcy received no rebuke from the council. ${ }^{181}$ The Administrative Office Director, charged with administering the bankruptcy system, protested to the Judicial Conference. Acting on the recommendation of its Committee on Bankruptcy Administration, that body "disapproved the practice as improper and detrimental to the proper administration of justice in bankruptcy cases." 182 Similarly, with the council remaining passive, a trial judge appointed as his secretary a man lacking in "qualifications for any grade of secretary to a federal judge."183 A committee of the Judicial Conference so found, and successfully urged that the full Conference instruct the Director of the Administrative Office to "remove him from the payroll forthwith."184

And so as Chief Justice Earl Warren observed in a different context, an instrumentality of national administration "tends to involve itself in many things which should be primarily of local concern." 185 But it intervenes "because the power given to local agencies to remedy admittedly bad situations is not exercised."186 It acts too because it represents a national constituency rather than a local or regional one, and because it possesses prestige and access to sanctions unavailable to the councils.

Yet, neither the Conference nor the Administrative Office are central offices for the management of the courts. On more than one occasion the Conference has felt constrained to resort to exhortation, calling on judges to use "the circuit councils to promote the efficiency of the courts and to execute the administrative policies laid down by law and by the Judicial Conference. . ..."187

180 Administration in the Federal Courts at 19.

181 Interview with John Biggs, Jr. in Wilmington, Delaware, Feb. 28, 1965.

1821961 JUDiCIAL CONFERENCE REPORT 42.

1831960 JUdictal CONFERENCE REPORT 9.

$184 \mathrm{Id}$.

185 Address of the Honorable Earl Warren, supra note 14, at 185.

186 Id.

1871960 JUdICIAL CONFERENCE REPORT 16. 
Some councils have acted, but not many and not often. When they have responded positively to administrative problems in their circuits, it was because their members believed that they were duty bound "to take the initiative ... in preventing nonfeasances and misfeasances, in anticipating difficult situations, and in taking steps to prevent difficulties which might otherwise arise."188 But this was easier said than done. As Chief Judge Charles E. Clark once observed, the councils' powers might be sweeping in principle, but in reality they were "so broad and general as to seem finally vague."189

Nowhere did reality depart so sharply from the ideal than when councils sought to placate demands made on them by Congress, the Judicial Conference, or local bars and thereby collided with strong willed judges. Confronted with resistance from such trial judges, councils have been thoroughly defeated in efforts to "set up at least some summer schedules"190 in the district courts, ${ }^{191}$ to remove a district judge's secretary, ${ }^{192}$ and to secure the retirement of the colorful District Judge for the Southern District of Ohio, Mell G. Underwood. When presented with a unanimous council resolution urging him to retire from the bench, Underwood allegedly retorted that " $[\mathrm{t}]$ hey have no authority to remove me, and they've found that out. I told them to go to hell. ..."193

\section{Strategies of Compliance}

Persuasion affords councils their initial and often sole strategy in implementing administrative policies. As one practitioner of the art put it, lifetime judges cannot "be bossed around-they respond to more delicate handling." 194 And more often than not this "delicate. handling" must come from the presiding judge of the court of appeals rather than from the collegial council which he heads. That body is ill-designed to "take the initiative, but can at most give the Chief Judge a little moral support."195 The chief judge, however, enjoys no special prerogatives as Judge Charles E. Clark, former dean of the Yale Law School, discovered. He thought himself "in a worse business

188 Stephens Papers, Box 28 (Justin Miller to D. Lawrence Groner, Jan. 29, 1944).

189 Clark Papers (Charles E. Clark to J. Edward Lumbard, Feb. 26, 1958).

190 Id. (Charles E. Clark to John W. Clancy, May 29, 1956).

191 See id. (John W. Clancy to Charles E. Clark, May 28, 1956).

192 Hearings on H.R. 11666 Before Senate Comm. On Appropriations, 86th Cong., 2d Sess. 508 (1960) (statement of Warren Olney, III).

193 Quoted in Frankel, Case for Judicial Disciplinary Measures, 49 J. AM. JuD. Soc'y. 218, 223 (1966).

194 Clark Papers (Charles E. Clark to Richard A. Merrill, April 5, 1963).

195 Id. (Charles E. Clark to J. Edward Lumbard, Jan. 5, 1961). 
than when [he] was dean" for he now possessed "no semblance of power whatsoever."196

Thus chief judges must seek to execute their council's policies by "wheedling,"19? a strategy which may bring results, ${ }^{198}$ but which may also prove futile. ${ }^{199}$ They appeal to flattery and to institutional loyalty in the face of congressional and judicial criticism and of threats, real and imaginary, of remedial legislation or budgetary retaliation. ${ }^{200}$ And to bolster their case, chief judges may obtain or cite existing resolutions of the Judicial Conference, note the deep concern of that august body expressed at its most recent session, ${ }^{201}$ or urge, as did Senior Circuit Judge Learned Hand, that a district judge behind in his work "act on this case, because when I go to Washington on the conference, this very matter will be mentioned, and they will say 'What happened here?" "202

A hard-pressed chief judge may even seek a Judicial Conference resolution on a particular issue in order to strengthen his hand in dealing with a recalcitrant judge. ${ }^{203}$ Conference words and attitudes may be readily invoked, but no chief judge can normally expect the chief justice nor individual members of the Judicial Conference to fight his wars for him. ${ }^{204}$

In the same manner that resolutions of the Judicial Conference may enhance the persuasive capacities of councils and their chief judges, so too imperative legislative language may assist them. Both the 1964 Criminal Justice Act and the Jury Selection Act of 1968 contain identical phrases stipulating that a district court "shall modify" its assigned counsel or jury selection plan when so directed by the judicial council of the circuit under the former act $^{205}$ and by the "reviewing panel" under the latter. ${ }^{206}$

196 Id. (Charles E. Clark to William Clark, May 31, 1956).

107 Interview with Richard H. Chambers in Washington, D.C., Jan. 26, 1965.

198 Clark Papers (Minutes of the Judicial Council of the Second Circuit, June 14, 1955). See also Stephens Papers, Box 28 (Justin Miller to D. Lawrence Groner, Jan. 29, 1944). 199 Letter from Learned Hand to Frank Cooper, Jan. 17, 1941, Administrative Office Correspondence, 60-A-328, Box 1; id., Cooper to Hand, Jan. 22, 1941.

200 Interview with J. Edward Lumbard, supra note 164.

201 Clark Papers (Charles E. Clark to Clarence G. Galston, March 15, 1956).

202 Hearings on H.R. 4394 at 244-5 (statement of Learned Hand).

203 Telephone interview with John Airhart in Washington, D.C., Feb. 5, 1965; interview with J. Edward Lumbard, supra note 164.

204 Clark Papers (Charles E. Clark to Earl Warren, May 15, 1956); id. (Earl Warren to Charles E. Clark, May 21, 1956).

20518 U.S.C. $\S 3006 \mathrm{~A}$ (a) (1964).

20828 U.S.C. \$ 1863(a) (1964). 
Studies by the Administrative Office can perform a function analogous to that of Conference resolutions or statutes. Seeking to alleviate the dockets in the Eastern District of New York, seriously clogged in the mid-1950's, Chief Judge Clark called on its resources after the 85-year-old court clerk allied with his chief judge blocked plans to establish a jury pool operated by an experienced calendar commissioner. ${ }^{207}$ An Administrative Office study, thought Clark, was "one way of building a fire under the aged gentleman." ${ }^{208}$ And when completed, the agency's recommendations were employed by him to move the clerk to action. ${ }^{209}$ This strategy proved highly successful, for the clerk, appointed during the presidency of Benjamin Harrison, not merely moved, but retired after sixty-five years of service in the Eastern District. ${ }^{210}$

Some difficult administrative problems necessitate more novel strategies. Persuading incompetent and senile judges to retire from active service as presiding officers of district courts ranked as the greatest challenge faced by a chief circuit judge prior to 1958 when Congress fixed a maximum age of seventy years for such officers. ${ }^{211}$ Chief Judge Charles Clark used an assortment of techniques to induce three chief district judges then in their mid-80's to step down from their administrative posts. He applied pressure on one judge's secretary, ${ }^{212}$ while in another case, he made "use of a sort of high-grade blackmail,"213 by threatening "that the Bar Association was going to take the matter to the newspapers." 214 The entire proceeding is tortuous, and as one chief judge recalled, "rather unpleasant, both for the person who goes to see the aged judge and ... for the aged judge himself."215

\section{Formal Council Sanctions}

Not all council policies are executed informally or by the chief circuit judge acting alone. They may be issued and implemented through formal processes, for the councils are empowered to "make all necessary

207 Clark Papers (Charles E. Clark to Will Shafroth, Dec. 17, 1955). See also Letter from Percy B. Gikes to Elmore Whitehurst, Oct. 7, 1955, Administrative Office Correspondence, 60-A-594, Box 3.

208 Clark Papers (Charles E. Clark to Will Shafroth, Dec. 17, 1955).

209 Charles E. Clark to Elmore Whitehurst, April 12, 1957, Administrative Office Correspondence, $60-\mathrm{A}-594, \mathrm{Box} .3$.

210 New York Times, Nov. 1, 1957, at 18.

21128 U.S.C. $\$ \S 45,136$ (1964).

212 Clark Papers (Charles E. Clark to Samuel C. Coleman, Oct. 18, 1954).

213 Clark, supra note 162, at 96.

214 Id.

215 Hearings on Judicial Fitness, pt. 1, at 15 (statement of John Biggs, Jr.). 
orders."216 And, stated the council of the Third Circuit, "having thus acted, its orders have the force of law."217

Such formal orders from the council to a district court or judge are very much the exception. The council in the District of Columbia "has never found it necessary or advisable to enter a formal order," while that in the Eighth Circuit has similarly relied on informal methods. ${ }^{210}$

When such formal orders are issued, they usually relate to the more mundane aspects of administration. Freezing a district judge's regular docket assignments until he has decided cases already under advisement is not uncommon, ${ }^{220}$ however unpopular it may be with trial judges. ${ }^{221}$ More dramatic and possibly ultra vires is the course of action proposed by Chief Judge Richard H. Chambers of the Ninth Circuit. He suggested to a Senate committee that a problem judge could be punished by temporarily assigning him to "a nonexistent place" where court was never held or to a place of court where little judicial business was generated.222 Utilized far less than the assignment power has been the council's power to certify a judge as physically or mentally disabled thereby reducing him to junior in status on the court and creating a vacant judgeship to be filled by the President. ${ }^{223}$

Even if a council never actually employed its formal powers, the mere threat to cancel a judicial assignment or to certify disability "has resulted in definite consequences in the form of action by the intended

21628 U.S.G. $\$ 332$ (1964). This power was not explicit in section 306 of the Administrative Office Act, 53 Stat. 1224, which provided that "It shall be the duty of the district judges promptly to carry out the directions of the council as to the administration of the business of their respective courts." The 1948 revision of the Judicial Code simplified the language and consolidated the delegation of power in a two sentence final paragraph:

"Each judicial council shall make all necessary orders for the effective and expeditious administration of the business of the courts within the circuit. The district judges shall promptly carry into effect all orders of the judicial council."

[Emphasis added.] The word "orders" was thus substituted for "directions." This change, stated a Judicial Conference committee in 1961, "would seem to have been one of form and emphasis rather than of substance."

H.R. REP. No. 201, at 2.

217 The Judicial Council of the Third Circuit, supra note 99, at 216, citing Yakus v. United States, 321 U.S. 414, 425 (1944). As they are not self-executing, council orders must be addressed to a judge or other officer of the court. Id.

218 Prettyman, supra note 66, at 634-5.

219 Clark Papers (Harvey M. Johnsen to J. Edward Lumbard, Dec. 14, 1960).

220 See letter from Henry P. Chandler to Harold R. Medina, January 8, 1952, Administrative Office Correspondence, 60-A-328, Box 4; Clark Papers (J. Edward Lumbard to Sylvester J. Ryan, Nov. 29, 1960).

221 Clark Papers (Sylvester J. Ryan to J. Edward Lumbard, Dec. 7, 1960).

222 Hearings on $S .3055$ at 249-52.

22328 U.S.C. § 372(b) (1964); Hearings on S. 3055 at 254 (statement of Joseph D. Tydings): 
subjects of the orders."224 Either order, if issued, would have reflected on the incumbent judge's physical and/or mental capacity. It constitutes a public vote of no confidence in him, and is aimed directly at his pride and vanity. A veteran magistrate, anxious to retain his hard-won reputation, can ill afford to ignore it, though some do. ${ }^{225}$

But the problem, which "has baffled the members of the judiciary," persists. ${ }^{228}$ "What happens," queried Judge John Biggs, "if a Council makes a decision and an order and directs a district judge to carry out ... that order and the judge refuses to do it?"227

No difficulty arises if a non-tenured officer of the court is the object of an order. A council may direct that the district court remove him from office for refusal to obey the order.228 Removal or other disciplinary steps by the trial court may be ordered notwithstanding the statutory language of section 332, which directs compliance with council orders by the district judges rather than by the court. The Judicial Council of the Third Circuit declared this distinction merely technical because "a court and the judges who dictate and direct its action are one." 228

A recalcitrant court employee such as a court reporter could also be disciplined by a proceeding in the district court brought "in the name of the judicial council to secure an order in the nature of a writ of mandamus to be directed to the reporter." The order so secured "would be ... a a 'necessary' and 'appropriate' aid to the jurisdiction of the district court for the court could not properly exercise its jurisdiction without the proper functioning of its reporter."230

However, deprivation of a judge's judicial power poses a truly serious issue in that it may infringe upon his judicial discretion and constitutional rights. At least one district judge has been removed from a case in which the court of appeals twice reversed him, ${ }^{231}$ while the Third Circuit removed all criminal cases from a judge suspected of corrupt practices. ${ }^{232}$ The Tenth Circuit in the Chandler case went even further. It ordered that the judge

224 Letter from Richard H. Chambers to Olin D. Johnston, June 20, 1961, supra note 63. 225 Interview with John Biggs, Jr., supra note 181.

226 Hearings on Judicial Fitness, pt. I, at 11 (statement of John Biggs, Jr.).

227 Id.

228 The Judicial Council of the Third Circuit, supra note 99, at 217.

229 Id. at 216-7.

230 Id. at 217; see also 28 U.S.C. § I651(a) (1964). The "All Writs" provision reads: "The Supreme Court and all courts established by Act of Congress may issue all writs necessary or appropriate in aid of their respective jurisdiction and agreeable to the usages and principles of law."

231 Comment, Judicial Performance in the Fifth Circuit, 73 YALE L.J. 90, 120 (1963).

232 Hearings on Judicial Fitness, pt. 1, at 19 (statement of John Biggs, Jr.). 
take no action whatsoever in any case or proceeding now or hereafter pending in the United States District Court for the Western District of Oklahoma; that all cases and proceedings now assigned to or pending before him . . . be reassigned to and among the other judges of said court; that until the further order of the Judicial Council no cases or proceedings filed or instituted in the United States District Court for the Western District of Oklahoma shall be assigned to him for any action whatsoever. ${ }^{233}$

In short, the council had "stripped Judge Chandler of his judicial authority and powers and left him only the shell of his office ... his office space, his desk, his robe hanging in a closet."234 Chandler's attorneys argued that his office had been effectively removed from him, thereby depriving him of his constitutional rights under article III, section $I$ and infringing upon the impeachment powers of Congress. ${ }^{235}$

An appeal to the Supreme Court in 1966 for a stay of the order brought no relief. Wary of interjecting itself into the dispute, the Court, by a 7-2 vote, held the issue unripe because the order was "entirely interlocutory in character pending further proceedings." 236 However, both Justices Black and Douglas sharply dissented, contending that enforcement of the order would mean "that Judge Chandler is completely barred from performing any of his official duties and in effect is removed or ousted from office pending further orders of the Council."237 The council, said the dissenters, "is completely without legal authority to issue any such order ... that no statute purports to authorize it, and that the Constitution forbids it."238

Although the Supreme Court failed to hand down a definitive pronouncement on the outer limits of the council's powers under section 332 in 1966, it heard further arguments on the still live Chandler case in December 1969. ${ }^{239}$ Nevertheless, in the light of that section's legislative history, it is manifestly clear that the framers of the Administra-

233 Notarized copy of original Order of the Judicial Council of the Tenth Circuit, In the Matter of the Honorable Stephen S. Chandler, United States District Judge for the Western District of Oklahoma at 3-4 (Special Session, Dec. 1965).

234 Brief for Petitioner, supra note 160 , at 17 .

$235 I d$.

236 Chandler v. Judicial Council of the Tenth Judicial Circuit of the United States, 382 U.S. 1003 (1966).

237382 U.S. at 1004; see Booth v. United States, 291 U.S. 339 (1934).

238382 U.S. at 1004.

239 Chandler v. Judicial Council of the Tenth Circuit, 395 U.S. 956 (1969) (miscellaneous order); Chandler v. Judicial Council of the Tenth Circuit, 38 U.S.L.W. 3217-8, 3220 (U.S. Dec. 16, 1969) (miscellaneous order no. 2). 
tive Office Act never intended to vest in the councils any power to deprive a judge of his office. Furthermore, both before and after passage of the Administrative Office Act, Congress considered separately and in depth this very issue of judicial removal by means other than impeachment. ${ }^{240}$ But at the time, constitutional arguments against such removal power prevailed although scholars and judges as well as legislators have been divided on the issue. ${ }^{24 x}$

In the absence of the ultimate sanction of removal, a council defied by a district judge might invoke the "All Writs" section of the Judicial Code ${ }^{242}$ and entertain a petition for a writ of mandamus or prohibition. ${ }^{243}$ A trial judge's violation of the terms of such a writ presumably could be punished by a contempt citation directed against him. ${ }^{244}$ Yet the efficacy of this procedure remains uncertain because until the Chandler case no judge had ever disobeyed one of the rare council orders, ${ }^{245}$ much less a writ of mandamus or prohibition. As the Supreme Court never reached the substantive issues in that case, obscurity continues to veil the enforcement of council sanctions.

\section{ReForm Proposals}

The circuit councils have long been subjected to criticism, some of it harsh. Yet in structure and powers, they differ little from those organized in 1939-40. This static quality reflects the desire of leading federal judges that institutions "functioning all right, should be left alone." ${ }^{48}$ It reflects, too, the belief of less sanguine magistrates that relatively few changes can be made in the councils because ultimately the only viable path to effective judicial administration lies in "cooperation and ... not ... purported policemanship." 247 This perception of administrative power largely defines the practical milieu within which any reforms of the councils must emerge.

Reform efforts have followed several paths. One has centered on

240 See Hearings on H.R. 2271 Before House Comm. on the Judiciary, 75th Cong., 1st Sess. (1937); Hearings on H.R. 146 Before Subcomm. of the Senate Comm. on the Judiciary, 77th Cong., Ist Sess. (1941) [hereinafter cited as Hearings on H. 14G].

241 The definitive study of judicial removal by statute remains that of Burke Shartel, Federal Judges-Appointment, Supervision, and Removal-Some Possibilities Under the Constitution, 28 MICH. L. REv., 870 (1930). Later articles have reiterated his arguments. Galls, Removal of Federal Judges-New Alternatives to an Old Problem: Chandler v. Judicial Council of the Tenth Gircuit, 13 U.C.L.A.L. Rev. 1385 (1966).

24228 U.S.C. $\$ 1651$ (1964).

243 See Hearings on Judicial Fitness, pt. I, at 13 (statement of John Biggs, Jr.).

244 Comment, supra note 231, at 122.

245 See Lumbard, supra note 179, at 169-72.

246 Hearings on S. 3055 at 244 (statement of Richard H. Chambers).

247 H.R. REP. No. 201, at 9. 
expanding the councils' statutory duties and increasing their formal powers as evidenced in the Criminal Justice Act of 1964 and the Jury Selection Act of 1968.

Related to this development have been repeated attempts by the Judicial Conference to obtain staff assistance for the councils, thereby relieving judges of assorted detailed administrative tasks. Although a remote descendant of Chief Justice Charles Evans Hughes' circuit administrative office plan, ${ }^{248}$ the immediate impetus for full-time salaried executive officers in the circuits came from the Criminal Justice Act. ${ }^{249}$ That measure required that the district courts establish a roster of attorneys eligible for appointment as counsel for indigent defendants. ${ }^{250}$ An executive secretary was perceived as one who would "help develop and apply administrative procedures at every stage," 251 maintain the attorney roster, ${ }^{252}$ and police the distribution of funds to private lawyers. ${ }^{253}$

By 1968, an American Bar Foundation study as well as Chief Justice Warren urged Congress to create an administrative officer for each circuit responsible to the council. ${ }^{254}$ Noting the wide variety of circuit problems and "the need to have management close to the problems," Warren in his 1968 American Law Institute address called for the establishment of circuit "administrative centers" or "management headquarters" each under the supervision of a "circuit administrator."255

This proposal struck a responsive chord in the Senate where Senator Joseph D. Tydings, chairman of the Subcommittee on Improvements in Judicial Machinery, introduced a bill requiring that each circuit council "appoint a court executive . . . who shall exercise such administrative powers and perform such duties as may be delegated to him by the circuit council."258

These duties included budgetary and statistical functions which bore a striking resemblance to those advanced by Chief Justice Hughes in

248 See note 24 supra.

2491964 Judictal Conference Report 91; 1966 Judicial Conference Report 3; 1967 JUDICIAI CONFERENCE REPORT 2.

250 I8 U.S.C. § $3006 \mathrm{~A}(\mathrm{~b})$ (1964).

251 Hearings on Departments of State, Justice, and Commerce, the Judiciary and Related Agencies Appropriations for 1966 Before Subcomm. of House Comm. on Appropriations, 89th Cong., 1st Sess. 114-5 (1965).

252 Id.

253 Id., 89th Cong. 2d Sess. 53 (1966) (statement of Matthew McGuire).

254 See P. Garrington, Accommodating the WORKLOAd of the UnIted States Courts of Appeals 3-4; Address by Earl Warren, Chief Justice of the United States, reprinted in Hearings on S. 3055 at 298.

255 Hearings on S. 3055 at 298 (statement of Earl Warren).

256 S. 952, 91st Cong., Ist Sess. § 9 (1969); S. 1509, 91st Cong., Ist Sess. (1969). See also S. 3062, 90th Cong., 2d Sess. (1968) (preceding bill). 
1938. ${ }^{267}$ Others involved personnel supervision and administration, ${ }^{258}$ "administrative control of all non-judicial activities of the court,"258 including record-keeping, ${ }^{260}$ studies of court administration and business, ${ }^{261}$ planning of circuit conferences and council meetings, ${ }^{262}$ and "establishing procedures for the calling of jurors . . . and controlling their utilization and payment." 263 The circuit administrator would, in addition, perform various liaison functions with other government agencies, ${ }^{264}$ the Administrative Office of the United States Courts, ${ }^{265}$ the Judicial Conference, ${ }^{286}$ and with "the courts of the various States in which the circuit is located, the Marshal's Office, State and local bar associations, civic groups, news media, and other private and public groups having a reasonable interest in the administration of the circuit."287

A more controversial reform thrust has focused on changes in council memberhip, namely the addition of district judge representatives. ${ }^{268}$ Bills introduced by Tydings in both the 90th and 91st Congresses provided for the seating on the councils of chief district judges equal in number to the appellate judges. ${ }^{269}$ Advocates of such representation regard the presence of lower court judges on the councils as a means of improving communications between appellate and district judges. ${ }^{270}$ More significantly, they perceive the district judge members as enhancing the authority of the councils and perhaps strengthening their propensity for action. ${ }^{271}$ It has been the absence of permanent spokesmen for the interests of the trial courts, say some reformers, which encourages council passivity. ${ }^{272}$ Judges of the courts of appeals, who themselves lack trial court experience, have reportedly taken "the

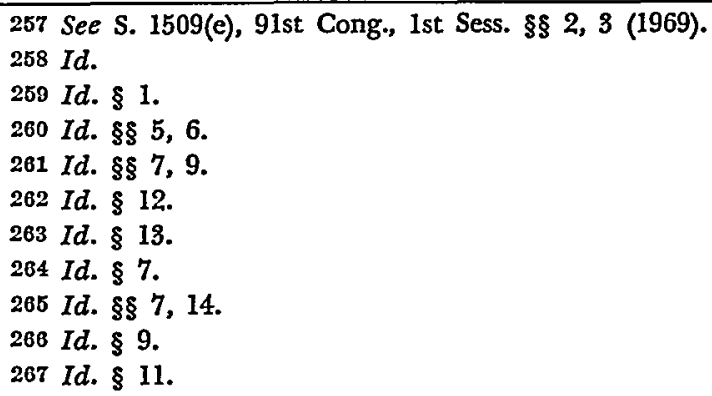
The membership of the reconstituted councils would not exceed eight judges excluding the chief judge of the circuit, S. 1514(c). Chief district judge representatives on the councils would be elected by a majority vote of all chief district judges within the circuit, S. 1514(d). For the District of Columbia Circuit, the district judge representation on the council would consist of the chief judge of the District Court for the District of Columbia and "the appropriate number of district judges in regular active service" selected in order of the dates of their commissions, S. 1514(d).

270109 CoNG. REc. 19736 (1963) (statement of Olin D. Johnston).

271 See supra note 6, at 195.

272 Biggs, Some Observations on Judicial Administration, 29 F.R.D. 464, 469 (1962). 
position that they do not know enough about the administration of a district court to enter an order relating to" its business. ${ }^{273}$

On the other hand, it has been precisely the fear that the addition of district judges was "intended to be a forerunner of pressures to increase the activity of such councils"274 that evoked opposition. At least one chief district judge did not "take kindly to the idea of having a Judge of another district court taking part in the supervision of our administrative action."275

Appellate judges, too, entertained misgivings. They objected to district judges sitting "in judgment on circuit judges," 276 and they contended that trial judges on the councils would only "add further paralyzing forces." 277 Difficulties would arise "in securing a consensus on what ought to be done in cases of possible misconduct, or the failure to handle court business, or the adoption of practices which may be contrary to professional and judicial ethics." 278 Noting that district judges sitting on appellate court panels exhibited a "slight tendency" to refrain from reversing judicial decisions pronounced by their peers on the trial court, ${ }^{279}$ Chief Judge J. Edward Lumbard of the Second Circuit Court of Appeals asserted it was "only natural and human for the chief judges of the district to defend practices which may be in question, or ... to urge that no action be taken with respect to conduct of one of their colleagues."280

In spite of sharp division over the inclusion of district judges on the councils, the September 1961 Judicial Conference, under intense pressure from Congress, ${ }^{281}$ discussed the issue "at length" and approved then pending legislation providing for representation. ${ }^{282}$ It reaffirmed this recommendation the following March. ${ }^{283}$ This action was taken in the face of rising opposition within the judiciary, ${ }^{284}$

273 Hearings on S. 3055 at 33 (statement of John Biggs, Jr.).

274 Id. at 67 (Resolution of the Judicial Council of the Ninth Circuit: Proposed Amendment of Section 332).

275 Clark Papers (Sylvester J. Ryan to Pierson M. Hall, Jan. 4, 1962).

276 Letter from Richard $\mathrm{F}$. Chambers to Olin D. Johnston, Dec. 21, 1961, supra note 63.

277 Clark Papers (Charles E. Clark to J. Edward Lumbard, Jan. 5, 1961).

278 Hearings on $S .3055$ at 262 (statement of J. Edward Lumbard).

$279 \mathrm{Id}$. at 270 .

280 Id. at 262.

281 See Clark Papers (Warren Olney, III to Olin D. Johnston, Feb. 5, 1962).

282 Id. See also 1961 Judicial CONFERENGe Report 67. The vote was 17 to 5.

2831962 Judicial Conference REPoRt 3.

284 See Glark Papers (J. Edward Lumbard to Kenneth Keating, Sept. 22, 1961); letter from Richard H. Chambers to Olin D. Johnston, supra note 276; Chandler, The Role of the Trial Judge in the Anglo-American Legal System, 50 A.B.A.J. 125, 129-30 (1964). 
opposition which proved decisive when the March 1963 Conference refused to reaffirm its approval of the bills. ${ }^{285}$

In the meantime a Special Committee of the Judicial Conference on the Responsibilities and Powers of the Judicial Councils had advanced a middle position between the status quo and formal statutory provision for district judge representatives. ${ }^{286}$ Congressional criticism, then strident, was muted by this strategy, and the organization of the councils remained unchanged. The judiciary was thus spared the vagaries of reform, and perhaps the pangs of effective administrative power as well.

Another thrust of the reformers has centered less on the councils themselves than on related elements in the administrative system. Among them have been proposals to augment the authority of the presiding judge of each court of appeals. It is, after all, largely his abilities as an administrator which determine "whether you have a successful and prompt administration of the business of the district or circuit."287

As a first step, Congress has required chief judges to relinquish their administrative duties at age seventy, ${ }^{288}$ a reform designed to infuse the position of presiding officer with men of youth and vigor. ${ }^{289}$ Not satisfied with merely modifying the judicial seniority system, reformers seek to abolish it altogether. They advance a variety of selection methods as substitutes; all of them are intended to produce chief judges with an interest in and enthusiam for administration. The plans suggested include appointment by the President analogous to his selection of the Chief Justice of the United States, ${ }^{290}$ by the Chief Justice as head of the federal judicial system, ${ }^{291}$ by the circuit councils in the case of chief district judges, ${ }^{292}$ and by the election

2851963 JUdicial CONFERENGe Report 9.

286 H.R. REP. No. 201, at 10, referring to 28 U.S.C. $\S 332$ (1964).

287 John Biggs, Jr., Transcript of Conference in re: Manner of the Selection of Chief Judges, Ninth Circuit, Dec. 20, 1955, at 10, Administrative Office Correspondence, 60-A-328, Box 31 [hereinafter cited as Transcript].

28828 U.S.C. §§ 45, 136 (1964).

289 See Clark Papers (Charles E. Clark to J. Edward Lumbard, Jan. 5, 1961).

290 Transcript, supra note 287 , at 85.

291 Id. at 86; Hearings on S. 3055 at 47 (statement of Albert B. Maris). But Chief Justice Earl Warren opposed lodging the appointment power in his office. See Clark Papers (Charles E. Clark to Paul B. DeWitt, Dec. 1, 1956).

292 Clark, The Role of the United States Court of Appeals in Law Administration, supra note 162, at 97 . 
process in the councils 293 or by the Supreme Court ${ }^{294}$ for the presiding officers of the appellate courts.

Finally, reformers look to higher strata of the administrative apparatus for remedies to seemingly insoluble problems on the district and circuit levels. Many issues of irregular judicial conduct and nonconforming administrative practices reach the Judicial Conference for final resolution. Yet even that national institution lacks the kind of sanctions with which to discipline errant judges whose acts of malfeasance or nonfeasance fall short of constituting those "high crimes and misdemeanors" warranting impeachment. It lacks any formal power to remove federal judges who hold their office during "good behavior." Nor do the councils enjoy this power, notwithstanding any inferences which may be drawn from the course followed by the Judicial Council of the Tenth Circuit in the Chandler case.

The "Judicial Reform Act" sponsored by Senator Joseph Tydings in the 90th and 91st Congresses offers a different approach. ${ }^{295}$ Rather than enlarging the functions and powers of existing institutions of judicial administration, Tydings' bill would establish a National Commission on Judicial Disabilities and Tenure. The Commission would consist of five members, including two district and two appellate court judges, appointed for four year terms by the Chief Justice. $^{206}$

The agency would be equipped with a permanent staff of its own ${ }^{297}$ and empowered to "administer oaths, order . . . the inspection of books and records, and issue subpenas [sic] for the attendance of witnesses and the production of papers, books, accounts, documents, and testimony. ..."298 Thus endowed, the Commission would investigate complaints of and hold hearings on judicial conduct alleged to be inconsistent with the "good behavior" required of article III judges. ${ }^{299}$ The Act defined such conduct as "willful misconduct in office or willful and persistent failure to perform ... official duties by a judge of the United States. . .."300

A finding by the Commission that a judge had in fact misbehaved would result in a report to the Judicial Conference "recommending

293 Agenda of the Meeting of the [Judicial Conference] Committee on Court Administration, Nov. 1, 1955, at 2, Administrative Office Correspondence, 60-A-328, Box 15. 294 Hearings on $S .3055$ at 268 (statement of Edward J. Lumbard).

295 S. 3055, 90th Cong., 2d Sess. (1968); S. 1506, 91st Cong., Ist Sess. (1969).

296 S. 1506, 91st Cong., 1st Sess. §§ 377(a)-(c) (1969).

297 Id. $\S \S 389$ (a)-(b).

298 Id. § 384.

290 Id. $\$ 379$.

300 Id. $\S 378(\mathrm{c})$. 
that the judge be removed from office."301 The Conference or one of its committees would then act as an intermediate appellate tribunal with power not only to "review the record, the findings, and the determination of the Commission, both on the law and on the facts," 302 but also to "receive additional evidence, hear oral arguments, or require the filing of briefs." ${ }^{303}$ With the right of further appeal to the Supreme Court by writ of certiorari preserved, the Conference might modify, accept, remand, or reject the Commission's recommendations. ${ }^{304}$ Should the Conference accept a recommendation for removal and, if subsequently reviewed and affirmed by the Supreme Court, then, after certification of the recommendation, the judge in question "shall be removed from office." 305

The Tydings proposal raises many of the same questions evoked three decades ago by Congressman Hatton Sumner's bills to try federal judges for misbehavior. ${ }^{308}$ Specifically, it poses an issue of the constitutionality of removing federal judges by means other than impeachment. Once that question is settled, a viable standard of "misbehavior" must be determined.

Proponents and their antagonists have long and vigorously debated in congressional hearings and scholarly publications the legal merits and demerits of judicial removal procedures exclusive of impeachment. ${ }^{307}$ Supporters contend that "the Constitution provides two methods of ouster of Federal judges, trial by impeachment, and trial by a court." 308 Impeachment rests on power delegated in articles I and $\mathrm{II}^{308}$ while the removal of judges by an instrumentality of the federal judiciary, such as a court or commission composed of judges, is founded on the "good behavior" provision of article III.

\footnotetext{
301 Id. $\S 378(\mathrm{~d})$.

302 Id. $\$ 379(\mathrm{~b})$.

$303 \mathrm{Id}$.

304 Id.

305 Id. § $379(\mathrm{e})$.

308 See note 240, supra.

307 No attempt is made here to consider in detail pro and con arguments. However see Shartel, supra note 241; Note, The Exclusiveness of the Impeachment Power Under the Constitution, 51 HARv. L. REv. 330 (1987); Hearings on H.R. 146; Davis, The Chandler Incident and Problems of Judicial Removal, 19 STAN. L. REv. 448 (1967). Comment, Courts-Judicial Responsibility-Statutory and Constitutional Problems Relating to Methods for Removal or Discipline of Judges, 21 RuTGERS L. REv. 153 (1966).

308 H.R. REP. No. 814, 75th Cong., 1st Sess. 4 (1937).

309 "The House of Representatives . . . shall have the sole Power of Impeachment" (art. I, ₹ 2); "the Senate shall have the Sole Power to try all impeachments" (art. I, § 3); "the President, the Vice President and all civil Officers of the United States shall be removed from Office on Impeachment for, and Conviction of Treason, Bribery, or other high Crimes and Misdemeanors" (art. II, \& 4).
} 
Critics of proposals to remove judges by means other than impeachment rely heavily on the historical evidence. They point to Alexander Hamilton's statement in Federalist No. 79 that impeachment "is the only provision ... which is consistent with the necessary independence of the judicial character, and is the only one which we find in our Constitution in respect to our Judges." Hamilton's unambiguous language, assert the antagonists, means that impeachment constitutes the exclusive method of removal. Thus they publicly "doubt whether . . . Federal legislation can constitutionally establish methods for adequately dealing with unqualified judges."

Should the Tydings bill wend its way to enactment and pass constitutional muster, it will provide, at least in theory, a potent weapon in the federal judiciary's arsenal. Even if it is little used, an instrumentality such as the National Commission on Judicial Disabilities and Tenure could play an important role. Chief Judge J. Edward Lumbard has predicted that its mere existence "will greatly strengthen the hands of the circuit councils in whatever it is that they have to do, even though most of what they do is done informally."311 Whenever an uncooperative judge "knows that there is . . a commission .. . which has the power to act," Lumbard thought, this fact alone would "take care of those situations where the recalcitrant judge otherwise would simply not obey the suggestion of the circuit council." 312

These words are strikingly reminiscent of those uttered three decades ago by judicial proponents of the Administrative Office Act of 1939. Then, the circuit councils were advanced as viable agencies for ensuring high standards of judicial conduct as well as for preserving, if not fostering, the independence of the federal courts. In spite of exhortations and added responsibilities, there have been few indications that the councils are anything but rusty hinges of federal judicial administration. They are either too far removed from district court administration or they are too close; they are too protective of judicial peers or too arbitrary; they are too laden with diverse duties or they are too impotent to execute them. They suffer, in short, from a multitude of shortcomings, some of which have brought the councils wide but unwanted publicity.

Proposed reforms may well revitalize these institutions and render them effective administrative linchpins. On the other hand, the time

310 Fearings on S. 3055 at 245 (Interim Report of the Committee of the Judicial Conference of the Ninth Circuit, July 1967, cited by Richard H. Chambers).

311 Hearings on $S .3055$ at 263.

312 Id. 
may have come to question the guiding principle of the 1939 Act and particularly of the councils, namely the distribution of administrative power among the eleven circuits. This "magic touch of decentralization," as Charles Evans Hughes' biographer has termed it, ${ }^{313}$ should perhaps be reappraised in the light of contemporary needs and of thirty years of practical experience with the circuit councils.

313 M. Pusey, Charles Evans Hughes 687 (1951). 